\title{
Economics and the \\ Social Meaning of Money
}

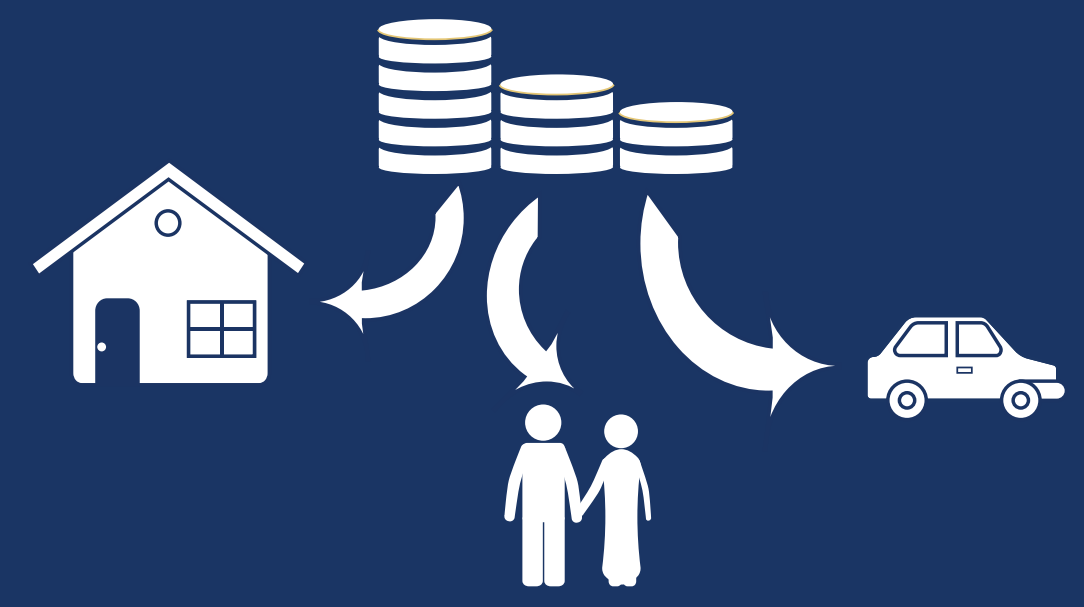

By: Jonathan Morduch, NYU 


\title{
Economics and the Social Meaning of Money ${ }^{1}$
}

\author{
Jonathan Morduch 2 \\ New York University
}

November 7, 2015

\section{In The Social Meaning of Money Viviana Zelizer steadily takes apart the idea of} fungibility — that a dollar is a dollar is a dollar. She argues that the notion that "money is a single, interchangeable, absolutely impersonal instrument" (Zelizer 1994, p. 1) fails to acknowledge the many ways that we separate, personalize, and earmark different sources of money. Zelizer shows how money received as charity is treated differently from gambling winnings, for example, or earnings from a 9-to-5 job. Money earned by husbands is often demarcated from money earned by wives, with different sets of expectations, obligations, and restrictions around how the money is spent.

Zelizer demonstrates that money touches so much of life that studying the meanings we attach to particular monies becomes a way to gain insight into our relationships with others and our self-understandings; our views of what is permissible,

\footnotetext{
${ }^{1}$ I have benefited greatly from conversations with Viviana Zelizer and participants at the Yale Money Talks symposium organized by Nina Bandelj and Fred Wherry, held on September 12, 2014. Viviana Zelizer and Tim Ogden provided particularly helpful comments on an earlier draft. This essay draws on work completed as part of The US Financial Diaries project, a collaboration between NYU's Financial Access Initiative and the Center for Financial Services Innovation. The principal investigators are Jonathan Morduch (NYU) and Rachel Schneider (CFSI). Support for the U.S. Financial Diaries Project is provided by the Ford Foundation, the Citi Foundation, and the Omidyar Network. I am alone responsible for all views and any errors. ${ }^{2}$ Professor of Public Policy and Economics, Robert F. Wagner Graduate School of Public Service, New York University.
} 
regrettable, and admirable; our anxieties and aspirations; our biases and blindnesses; and where lines are drawn between necessities and luxuries.

Zelizer deploys archival evidence on approaches to earning and spending in the United States to challenge arguments -- from Karl Marx's ([1867]) critique of commodity fetishism to Georg Simmel's ([1900]) depiction of the anonymizing role of money -- that view market exchange mediated by money as inevitably impersonal and often depersonalizing. In this way, Zelizer positioned The Social Meaning of Money to enter a conversation in economic sociology around the market and society, an inquiry into the power and limits of the market system.

Zelizer's evidence and interpretation, though, speaks to a wider set of concerns. Approached from the perspective of economics rather than economic sociology, Zelizer's evidence can be seen as laying down a challenge to a different set of ideas - i.e., depictions of household choice developed and defended in works such as Gary Becker's Treatise on the Family (Becker 1981) and related texts that became central to neoclassical micro-economics in the 1960s through 1990s (Bergstrom 1996). This was not Zelizer's intended target, but, with the passage of time, we can see how the frameworks square off against each other.

In this frame, the evidence presented in The Social Meaning of Money can be redeployed as a critique of the way that fungibility was asserted by Chicago School economists. ${ }^{3}$ The Chicago School canon builds a case for flattening various forms of conflict and differentiation within families, and it pushes away from focusing on

\footnotetext{
${ }^{3}$ Ironically, in the introduction to Economic Lives, Zelizer (2011, p. 16) invokes Gary Becker in an aside, noting that Talcott Parsons had described being on the "warpath" against ideology associated with Becker - and suggested that Zelizer watch out not to be confused with Becker's positions. There is no risk of such confusion in The Social Meaning of Money.
} 
differences in preferences as explanations for household choices. This flattening - and its focus on the roles of prices and incomes in determining choices -- came to define neoclassical analyses of "the economics of the household" (e.g., Becker 1974, Stigler and Becker 1977, Becker 1981). Here, The Social Meaning of Money plays a counterpoint not to the left but to the right. Zelizer's work shows that the assertion of fungibility may have been productive for Chicago School analyses, but it's not productive when trying to understand a broader set of questions about human relations and household choices.

Economists find two types of justification for assuming that money is fungible within households. The first stems from a view that differences in preferences within families are apt to be minor. As a result, for all intents and purposes, the household can be treated as if it acts with one head whose task is to solve a grand optimization problem encompassing all household economic choices. This is an empirical claim with important theoretical implications. If it is true that the household can be imagined as if it was a comprehensive planner with relatively stable and consistent preferences, the analytical focus can then turn to how prices and various constraints drive choices.

Stigler and Becker (1977) capture this spirit in the title of their essay “De gustibus not est disputandum" (there is no arguing about differences in preferences). Their position is that, in principle, differences in preferences - including differences in preferences within families -- may explain some choices but that, in practice, the explanatory power of differences in preferences is usually far weaker than that of variation in prices and incomes. Once conflicts over preferences are removed from consideration, assuming the fungibility of money flows with little contest. From there, it follows that the task for economists is not to spend much time on the genesis of preferences, nor on intra-household conflict, but instead: "On our view, one searches, 
often long and frustratingly, for the subtle forms that prices and incomes take in explaining differences among men and periods" (p. 76). ${ }^{4}$ The view is contested (see McCloskey 1993) but remains a core of modern micro-economics.

The second justification for asserting the fungibility of money in budgeting is purely practical. Fungibility is not the most hallowed assumption in empirical economics, but it is among the most useful -- and economists are understandably reluctant to give it up. Invoking the fungibility of money makes much of empirical household economics possible - or at least far simpler. Once the assumption is accepted, economists can collect data from households composed of different strands of individual activity, and then aggregate those data into sums (total household income, total household consumption) that can be plotted, regressed, and submitted to empirical scrutiny as if the data reflected the constrained optimization of a well-defined, unified decision-making unit. Given that most economic surveys collect data on households rather individuals (what did the household buy this year? How much did the household earn?), the assumption makes most empirical analyses of households possible. Even if one wants to probe within households, the data do not allow researchers to go far (Deaton 1997). Non-fungibility is a hard sell.

This perspective on The Social Meaning of Money allows a different appreciation of Zelizer's contribution. It also offers one sense of how Zelizer's work is "heard" by economists. That context starts by recognizing how useful the fungibility assertion was

\footnotetext{
${ }^{4}$ Stigler and Becker (1977, p. 76) are blunt on the division of labor between economists and other social scientists: "On the traditional view, an explanation of economic phenomena that reaches a difference in tastes between people or times is the terminus of the argument: the problem is abandoned at this point to whoever studies and explains tastes (psychologists? anthropologists? phrenologists? sociobiologists?).” Ferber and Nelson (1993) take a broader view of possibilities within economics - including research that takes intra-household dynamics and nonpaid work seriously.
} 
to Gary Becker and his colleagues in narrowing their scope of inquiry - and how essential it continues to be for generations of economists analyzing household data sets. Against those benefits, Zelizer shows that the assumption of fungibility limits understandings of the mechanics of individual economic choices and what they say about the nature of human relations. When one dollar is the same as any other dollar, there is little scope for earmarking and differentiating income streams by social meanings. Becker's approach not only dismisses concern with the genesis of preferences -- which may be a useful way for economists to reinforce disciplinary boundaries -- but, perhaps unintentionally, prevents economists from probing the earmarking of income as a form of consumer decision-making. The latter inquiry, I argue, should be squarely within economists' range.

No matter how much economists are discomfited by hearing her arguments, windows (and ears) are opening. As Zelizer found in her archival research, evidence for non-fungibility spills out from micro data about the decision-making processes of households. The accumulating "anomalies" are pushing economics to open up from within (Kahneman et al. 1991; Thaler 2015), so that when economists consider reasons for failure of the assumption that money is fungible, they now have at hand at least two well-established directions for departing from Chicago School orthodoxies, both of which exist within the economic mainstream (including at the University of Chicago). The first comes from bargaining theory and the second from behavioral economics. Adding Zelizer's notion of social meanings of money into the conversation provides alternative hypotheses for explaining phenomena usually ascribed to bargaining or behavioral economics. More important, it provides ideas for creating testable, practical interventions that work by evoking social meaning and that rely on earmarking. 
Several well-known examples of successful policy interventions are framed as working due to insights from game theory or behavioral economics - for example, the use of conditional cash transfers as an alternative safety net and notions of "mental accounts" to increase household saving. Turning to Zelizer's work shows how, in practice, the interventions also work by evoking social meanings and earmarks. These ideas are described below in the context of new evidence on the social meaning of money drawn from the US Financial Diaries project.

\section{The Social Meaning of Money: Evidence from the US Financial Diaries}

Zelizer's insights may contrast with canonical Chicago-style household economics, but they are manifest in evidence on the day-to-day financial choices of low-income Americans, including the US Financial Diaries project. The project involved research teams that set out to track every dollar that 235 households earned, spent, borrowed, saved, and shared over the course of a year. The samples were drawn from sites in California, Mississippi, Kentucky, Ohio, and New York City. Roughly one third of the sample is poor, another third hovers above the poverty line, and a final third is in the bottom and middle of the middle class. The project is unusual in tracking highfrequency data through the year and systematically tracking finances, both formal and informal. I led the work jointly with Rachel Schneider of the Center for Financial Services Innovation, and as we tracked households' finances, we also followed their health crises, job crises, personal crises, and various successes and challenges. ${ }^{5}$

\footnotetext{
${ }^{5}$ The household stories described here are part of unpublished research with Rachel Schneider being completed for a book on the Diaries families. Details on the US Financial Diaries project
} 
Two examples from the Financial Diaries show different instances in which - in the spirit of Zelizer (1994) -- families demarcate or label monies to transform meanings. In Mississippi, we met a woman named Susan (names and some details have been changed to preserve confidentiality). Susan has a small store within a flea market where she sells antiques and used goods. She's 51, with two teenagers at home and an older child living on his own. "I've been here all my life except for 5 years and 10 months," Susan announced in response to a question about her background. The 5 years and 10 months were spent in prison on a conviction for selling drugs. Susan regularly attends church, but she isn't always able to come up with the money for the 10 percent weekly tithe typically made by the church's members. She laughs as she recalls once being at a church revival, before her years in prison, and tithing against her drug-selling proceeds. Susan recognizes a subversive element in tithing that money. ${ }^{6}$

When she was incarcerated, Susan also "tithed" against the $\$ 50$ gifts that her husband gave her to buy supplies at the prison store. Rather than tithing to the church, she made a point to give a share of the $\$ 50$ to prisoners who didn't have a husband or someone else to provide money. Her husband wasn't happy, though, since he saw the $\$ 50$ as his gift to her. For Susan, though, tithing against the $\$ 50$ brought her closer to the practices of the world outside, enabling her to feel a sense of agency as a giver not just a passive recipient. Tithing in that way allowed her to transform the nature of the

are available at www.usfinancialdiaries.org and in Morduch and Schneider (2013). The project uses the tools of empirical corporate finance to track income statements, balance sheets, and cash flow statements for each household. For a related approach, see Samphantharak and Townsend (2009). The methodology was established by Collins et al. (2009).

${ }^{6}$ The story contrasts with instances in which people are reluctant to give charity from criminal earnings; Zelizer (1994 p.3), for example, describes a gang member who refuses to donate "dirty" money to the church. Zelizer notes that sometimes "sullied" money can be "laundered" by donating part of it, which may have been part of Susan's motivation. 
cash flow from being a gift granted by her husband and turn it into an entitlement: her deserved share of the family's earnings, a notion that was reinforced by her desire to tithe against it.

Another time, Susan recalls arguing with her husband about whether one needs to tithe against social security. Her husband argued no, since one already tithes when the income is earned in the first place. For Susan, though, the logic of tithe as tax wasn't fully convincing. "I'm still confused about that," Susan muses, unsure about how to think about money that isn't subject to sharing.

Dolores lives in San J ose. Her father, an immigrant from Mexico, spent his life as a farm worker in the agricultural valleys of Northern California. Dolores has worked diligently to bring her own family into the middle class. Her husband, Antonio, works steadily as an auto mechanic, and Dolores is a manager at a local nonprofit. They lost a house to foreclosure when housing prices crashed in 2007 and now live in a mobile home, sharply paring their expenses to stay free of debt. To save money, Dolores prepares lunch for Antonio and herself every morning. They only eat out on weekends, and family activities often involve visits to state parks.

Dolores and Antonio have suffered for their choices; Dolores's siblings complain that Dolores and Antonio have cut themselves off by sticking rigidly to a budget rather than partaking in family celebrations. Still, Dolores takes it in stride and continues to budget carefully. Paychecks are automatically deposited at their credit union and then a portion is automatically invested in a retirement account. The rest of Dolores's paycheck goes to an emergency fund. Antonio's regular paycheck is earmarked for all the bills. But Dolores and Antonio also earmark money, earned from Antonio's "side work" fixing motorcycles, "Our side money goes into this pile where we can go and do our fun stuff." 
Having that extra pile earmarked - both protected and liberated -- makes it easier for Dolores and Antonio to budget aggressively everywhere else.

\section{Earmarks and Optimization}

The stories of Susan and Dolores, and the evidence that runs through The Social Meaning of Money, provide contrasts with assumptions that drive the neoclassical "economics of the household." Gary Becker was pivotal in making the household a serious focus of economic inquiry, but in Becker's (1981) most central work, the household is depicted as a decision-making unit that operates through consensus (or as if there was consensus). In typical formalizations, Becker begins with a utility function that reflects a household's preferences over goods or services $Z_{1}, Z_{2}, Z_{3}$, and so forth: $\mathrm{U}\left(\mathrm{Z}_{1}, \mathrm{Z}_{2}, \mathrm{Z}_{3}, \ldots\right)$ as if decisions by the household could be analyzed in the same way that decisions by individuals are analyzed. In this frame, Susan and her husband would work out their differences and make choices through consensus (or, equally well from the standpoint of theory, through Susan or her husband dictating decisions to the other). To highlight the way that the household becomes homogenized as a unit, the formalization is sometimes called the "unitary" household model. In Becker's framing, household utility is maximized subject to a household level budget constraint where each of the goods or services has a price $\mathrm{p}_{1}, \mathrm{p}_{2}, \mathrm{p}_{3}$, etc. Most important, all sources of household income are aggregated to create a common pool: $Y=Y_{1}+Y_{2}+Y_{3} \ldots+Y_{N}$. Here, Susan's drug earnings would not be differentiated from her husband's social security checks. The budget constraint is then $Y \geq p_{1} Z_{1}+p_{2} Z_{2}+p_{3} Z_{3} \ldots+p_{M} Z_{M}$. The pooling of income implies that all income is fungible and all spending is decided via a grand optimization 
problem undertaken by the household. Zelizer in effect warns us that the act of writing $Y$ $=\mathrm{Y}_{1}+\mathrm{Y}_{2}+\mathrm{Y}_{3} \ldots+\mathrm{Y}_{\mathrm{N}}$ is not an innocuous step. ${ }^{7}$

The kind of earmarking described by Zelizer (1994) stems from a different kind of decision process. Perhaps a form of optimization is in the background, but choices arise from processes other than comparisons involving the marginal utility of this equaling the marginal utility of that. Instead particular income flows are separated, demarcated, and earmarked early on, before specific consumption choices are made. Antonio's "side money" from fixing motorcycles is protected for the family's "fun stuff," for example, and the amount of fun stuff depends on how much accrues in the extra pile. HalpernMeekin et al. (2015), in another example, echo Zelizer's (1994, ch 4) analysis to show how recipients wall off tax refunds fueled by the Earned Income Tax Credit and spend the money differently from other transfers and income sources. A particular income flow may be fully assigned to a particular expense, such as $\mathrm{Y}_{1}=\mathrm{p}_{1} \mathrm{Z}_{1}$ or perhaps the earmark involves a set of expenses, like $Y_{3}=p_{3} Z_{3}+p_{4} Z_{4}$. Some income flows (say, $Y_{4}$ and $Y_{5}$ ) might be pooled together and allocations of those might arise subject to constrained optimization, but Zelizer's interest in The Social Meaning of Money is in the earmarks rather than the subsequent optimization choices. Zelizer points our attention to the logic of the demarcations and separations (is it right to tithe from drug sales?) and what they can tell us about household relations and their social contexts.

Why does Beckerian analysis ignore earmarks? Part of the answer is that as an empirical matter, it might not do great damage to analyze households as if spending arises from a grand optimization problem, even if, in practice, some money gets

\footnotetext{
${ }^{7}$ Zelizer (1994, p. 43) makes reference to the unitary household model by way of discussion of Amartya Sen's depiction of the "glued-together” household.
} 
earmarked. Dolores and Antonio might spend roughly the same on "fun stuff" even if Antonio's side money were pooled with their other earnings to determine all spending en masse. Dolores's and Antonio's choice to earmark the side money may have already accounted for a rough sense of Antonio's extra earnings together with an approximation of their anticipated spending on fun. If the "as if" statement roughly holds, earmarks can be acknowledged as being important to the process of spending, while only holding minor interest when studying broad patterns of outcomes. Economists are, after all, dogged consequentialists. Economists care how much gasoline is purchased, but seldom whether it was purchased at Exxon or BP or who in the family filled up the tank. Economists are more interested in the outcomes from optimization than whether choices arise via particular paths. The main challenge, then, in getting economists to pay attention to earmarks is to demonstrate if, how, and when earmarking affects outcomes.

The mathematical simplifications may be loaded, but they have been productive for neoclassical economists. Most immediately useful, the grand optimization problem in which all household income sources are pooled and all consumption choices are centralized - yields choices analyzable with the tools of marginal analysis in the spirit of Walras ([1874]). That leaves neoclassical economists on familiar ground. Economists know that no households literally tote up all their income and optimize all their spending in one giant mega-calculation. It is enough to know that approximating the actual process through this mathematical fiction comes reasonably close to reality. Does the grand optimization fiction in fact do a reasonable job? Becker (1981) shows how the unitary household model can be deployed to explain the impacts of budgets, costs, and 
wages on broad trends in fertility, marriage, divorce, the gendered division of labor, among other topics at the intersection of sociology and economics. ${ }^{8}$

But as an economic sociologist, Zelizer is interested in the nature of choices, the process of decisions, and the genesis of preferences - and what they mean for understandings of society and markets. Assuming the fungibility of money within the household may be productive for Becker, but it is not clearly productive for a broader range of inquiries -- and it hides all the vital action for Zelizer. Moreover, the grand optimization frame and the fungibility assumption hide some of the action for economists too.

\section{Departing from Fungibility: Bargaining}

Family members earmark money for a reason, and that purpose is often to steer budget allocations away from where a grand optimization would lead. Family members can disagree, often sharply. Questions around gender require recognition of conflict, whether potential or outright. Like Susan and her husband, couples may have very different ideas about how to spend money - and decisions reflect who controls which resources. Here, one dollar is not the same as another dollar since bargains depend on who controls which resources. Economists have created space for these concerns by introducing conflict as noncooperative or cooperative games of strategy between family members, where relative power is determined by control over resources (McElroy and Horney 1981, Browning and Chiappori 1998; see also, from an economic/ sociological perspective, Bittman et al 2003, England and Folbre 2005).

\footnotetext{
${ }^{8}$ In this work, the budget constraint is often joined by a parallel constraint on the use of time.
} 
The simplest case involves husbands and wives spending their incomes completely independently. Money earned by the wife is then clearly not the same as income earned by the husband, a case that often arises in The Social Meaning of Money. Rather than spending completely independently, husbands and wives may instead make joint decisions -- but the ultimate choices depend on the relative bargaining power of husbands and wives. Again money is not fungible - here, because control over income matters and reallocating between husbands and wives can tip the balance of power and thus the nature of negotiations.

As Viviana Zelizer notes in an essay on gender and money (Zelizer 2011), Grameen Bank of Bangladesh targets their loans to poor women partly as a way to push household spending toward education, health, nutrition, and general household welfare - with the assumption that men would be much less likely to spend so heavily on family needs. Similarly, in an influential study, Duncan Thomas (1990) reports that average nutrition and child health in urban Brazil improved much more when income was in the hands of women rather than men. With respect to survival probabilities, Thomas finds that income in the hands of a mother had, on average, twenty times the impact of the same income in the hands of a father. Thomas's finding, along with similar findings from elsewhere, influenced the design of Mexico's widely-replicated conditional cash transfer program (a safety net program that requires recipients to have met educational and health goals). The program directs payments to mothers, rather than fathers, and it has become a model for global safety net programs like Brazil's Bolsa Familia (Levy 2006, Zelizer 2011).

The non-fungibility of money is thus embraced when it seems pivotal (and when it can be linked to a familiar bit of economic theory). While economists embrace this 
reality, there is still distance to go before an economist would necessarily interpret this source of non-fungibility as being bound up with social meanings specifically. There must be conflicts over spending preferences for intrahousehold bargaining to matter, but here the source of those conflicts do not necessarily stem from money being earmarked or demarcated according to social meanings. Preference differences are sufficient to explain the result, and economists stop there. Economists have mostly been uninterested in the reasons for those preferences, uninterested in whether they stem from deep psychological bases or social constructions. ${ }^{9}$

To get at the role of social meanings and earmarking, an economist might ask a more subtle question raised by bargaining theory: Is a particular stream of income earned by husbands (or wives) fungible with other streams of money that the same individual earns? If not, then a student of bargaining theory will be reluctant to conclude that the fact that a wife's earnings is spent differently than her husband's income necessarily stems from particular social meanings or the earmarking of that stream. Instead, economic conversations would begin and end with issues of power and control. ${ }^{10}$

\footnotetext{
${ }^{9}$ As noted in a footnote above, Stigler and Becker (1977, p. 76) dismiss - too hastily and unfairly in my view -- these concerns as the province of "psychologists? anthropologists? phrenologists? sociobiologists?”

${ }^{10}$ Even here, there may be different propensities to spend from different pots of income because some income is perceived as being "permanent” (steady and reliable) and some, like lottery winnings, as "transitory." The permanent income hypothesis of Friedman (1957) suggests that a large chunk of the lottery winnings should be saved by a prudent optimizer. To set aside complications raised by the saving-spending decision, fungibility might be best probed by investigating the composition of spending by an individual, controlling for their total spending and then investigating whether the source of income matters to the compositional choice.
} 


\section{Departing from Fungibility: Mental accounts}

In the twenty years since The Social Meaning of Money was published, the influence of psychology has been deeply felt in large parts of empirical microeconomics. Most economists no longer rigidly adhere to the assumption that individuals are fullyrational, calculating beings. Instead, thanks to behavioral economics, economists are as likely to acknowledge cognitive biases, difficulties following through on plans, unresolved internal conflicts, and rules of thumb that get used in place of precise optimization. Behavioral economics has helped explain a range of economic outcomes, including why people don't save as much as they plan, run up unsustainable credit card bills, and hold on to poorly-performing investments rather than selling them (Tversky and Kahneman 1981, Thaler 1999, Thaler and Sunstein 2008).

This is where economists have embraced a form of earmarking. The integration of psychology and economics turns attention to difficulties sustaining attention and enforcing self-discipline, coupled with unresolved internal inconsistencies (decisionmakers may both want to spend now, for example, but also recognize the value of saving money). Solutions can lead to departures from the fungibility premise as people use and create "mental accounts" that demarcate and label different pots of money in order to maintain the salience of a given need or to remind individuals that the pots are only to be touched for particular purposes. The dollars in mental accounts may be demarcated through versions of the "tin can accounting" described by Zelizer (1994, p. 4) or more sophisticated modes like digital accounts on smart phone apps. The behavioral economics literature, though, rarely focuses on the earmarking of particular income streams. Instead, the focus is mostly on the way that money is earmarked once placed into a particular account (or digital wallet or tin can). In this way, Gary Becker's 
intrahousehold fungibility assumption is left intact (since the source of income is irrelevant in the analysis), while non-fungibility and earmarks emerge as part of the execution of consumption and saving decisions that emerge from a traditional optimization process. ${ }^{11}$

Ashraf et al (2006) provide one example. They measure the impact of giving an extra saving account (with a commitment feature similar to a "Christmas Club") to customers of a Philippine bank. Women (but not men) experienced dramatic increases in savings thanks to the ability to specially protect a portion of their savings, an impact interpreted as a response to "present bias" - a divided self with regard to saving. A second example is from Soman and Cheema (2011) who also study saving innovations. In their study in rural India, a sample of laborers was presented with a series of interventions. In one, a target saving amount was determined and half of the laborers were told the deposits would be placed in a sealed envelope; the other half were told that the money would go in two sealed envelopes. (The envelopes could be opened by the laborers and the money could be withdrawn if needed.) The effect of the partitioning (i.e., having two envelopes) turned out to be strong, presumably because the laborers could attach different labels to the two envelopes and, if they withdrew money, would stop by emptying the contents of one envelope rather than both. Both results show the power of demarcation.

\footnotetext{
${ }^{11}$ Behavioral economics is both a radical break for economics and, from a different angle, only a minor threat. The pioneers deftly balanced the forces of disruption and harmony. The particular focus on psychology can be seen as providing a safety valve, a way to embrace a set of empirical anomalies without jettisoning much of the broader apparatus. Behavioral economics provides another set of constraints to add to the optimization problem but does not jettison the optimization problem itself. There is still a clear optimization problem, and it is still the focus of study. We may recognize that some people are naïve and some are sophisticated about their biases, but the sophisticated ones get the most attention; their biases are modeled and their actions are tested.
} 


\section{Flipping things around}

Reading Ashraf et al. (2006) and Soman and Cheema (2011) in the context of The Social Meaning of Money pushes attention to particular parts of their study designs. In keeping with behavioral economics, the new saving accounts introduced in Ashraf et al. (2006) are interpreted as working thanks to the commitment features of the accounts (money is not allowed to be withdrawn before a certain time has passed or saving goal has been reached). But the actual design has other components: the marketing around the accounts also reinforces the social elements. The pamphlet asks: "Do you want to finance your own business? Thinking, where you can secure tuition fee payments? Do you want a high standard of living? MAKE YOUR DREAMS COME TRUE!” A certificate signed by each account holder requires them to fill in the blanks in the sentence in a way that creates an earmark: "If I achieve this goal, I will be able to enjoy my savings to by _____." On one hand, this is simply marketing, but on the other, the way it works is by encouraging -- and permitting -- users to label money and spend it for prized purposes. Given that, it is noteworthy that the intervention had no measured impact on saving by men, but it made a large and significant impact on saving by women. ${ }^{12}$

Soman and Cheema's (2011) study design addresses social elements directly. An additional intervention, layered over the intervention with the one or two envelopes, involves attaching a photograph of the laborer's children to the envelope. The idea is that savings were often earmarked for children's expenses, and the photos are a

\footnotetext{
${ }^{12}$ Ashraf et al. (2006) recognize the issue and control for marketing by adding a pure marketing intervention to the design (with no new saving account) that serves as an additional comparison. Their main result, though, is for the combination of the marketing and saving account intervention.
} 
reminder of that obligation. Soman and Cheema find an additional impact of the photo, over and above the impact of partitioning. While behavioral economists highlight the way that the photo increases the salience of the saving need, the manipulation also generates particular social meanings and reinforces the imperative to maintain the earmark on family spending. In a similar way, the saving interventions in Kenya analyzed by Dupas and Robinson (2013) are viewed within a behavioral frame, yet their impact is also surely due to the social meanings attached to the deposits, acquired through the explicit framing of the accounts as a way to accumulate for health needs.

The conditional cash transfer programs like Mexico's Progresa/ Oportunidades are also seen as succeeding by channeling resources to women. But they work too by reinforcing the notion that the particular funds are meant for improving family welfare, even if, in practice, there are no restrictions placed on how they are spent. Grameen Bank too works with its members to reinforce the idea that profits earned from loans should be earmarked for household welfare, even if there are no actual restrictions. Thus, social meanings and earmarks are at play, even if kept in the background in typical economic analyses.

\section{Conclusion}

Economics textbooks describe money as a store of value, a medium of exchange, and a unit of account. But in The Social Meaning of Money, Viviana Zelizer shows that money has a life within social contexts. Different income flows can be transformed through labels, earmarks, and meanings that people attach to various income sources. In that sense, money - and the way it is perceived - has a fourth role for social scientists. It can serve as "data" on social norms and relationships within households. 
Economists are more comfortable with the idea of earmarking funds in particular saving accounts (a mainstay of behavioral economics) than with the idea of earmarking particular income sources. The accumulating evidence echoes the archival evidence in Zelizer (1994), however, showing that earmarking income is a common mode of budgeting, especially when resources are scarce and relationships within households are conflictual. There is much more work to be done in exploring the phenomenon with an economic lens.

The Social Meaning of Money too shows how preferences develop and are reinforced by social contexts. Economists have not yet paid much attention to preference formation, but the work so far suggests that it is a promising path for empirical inquiry, especially as researchers look to next steps in understanding the economics of gender and the nature of decision-making under conditions of substantial scarcity.

\section{References}

Ashraf, Nava, Dean Karlan, and Wesley Yin. 2006. "Tying Odysseus to the mast: Evidence from a commitment savings product in the Philippines."Quarterly J ournal of Economics 121(2): 673-697.

Becker, Gary. 1974. "A Theory of Social Interactions.” J ournal of Political Economy 82 (6): 1063-1093.

Becker, Gary. 1981. A Treatise on the Family. Cambridge, MA: Harvard University Press.

Bergstrom, Theodore C. 1996. "A survey of theories of the family." In Mark Rosenzwerg and Oded Stark, eds., Handbook of Population and Family Economics. Amsterdam: North-Holland.

Bittman, Michael, Paula England, Nancy Folbre, and George Matheson. 2003. "When does Gender Trump Money? Bargaining and Time in Household Work." American J ournal of Sociology 109: 186-214. 
Browing, Martin and Pierre-Andre Chiappori. 1998. "Efficient Intra-Household Allocations: A General Characterization and Empirical Tests." Econometrica 66(6): 1241-1278.

Collins, Daryl, J onathan Morduch, Stuart Rutherford, and Orlanda Ruthven. 2009. Portfolios of the Poor: How the World's Poor Live on $\$ 2$ a Day. Princeton, NJ : Princeton University Press.

Deaton, Angus. 1997. The Analysis of Household Surveys: A Microeconometric Approach to Development Policy. Baltimore: J ohns Hopkins University Press.

Dupas, Pascaline, and J onathan Robinson. 2013. “Why Don't the Poor Save More? Evidence from Health Savings Experiments." American Economic Review 103(4): 1138-71.

England, Paula and Nancy Folbre. 2005. "Gender and Economic Sociology.” Pp. 627-49 in Neil Smelser and Richard Swedberg, eds., The Handbook of Economic Sociology, second edition. New York: Russell Sage Foundation and Princeton: Princeton University Press.

Ferber, Marianne and J ulie Nelson, eds. 1993. Beyond Economic Man: Feminist Theory and Economics. Chicago: University of Chicago Press.

Friedman, Milton. 1957. A Theory of the Consumption Function. Princeton, NJ : Princeton University Press.

Halpern-Meekin, Sarah, Kathryn Edin, Laura Tach, J ennifer Sykes. 2015. It's Not Like I'm Poor: How Working Families Make Ends Meet in a Post-Welfare World. Oakland, CA: University of California Press.

McElroy, Marjorie and Mary J ean Horney. 1981. "Nash-Bargained Household Decisions: Toward a Generalization of the Theory of Demand." International Economic Review 22(2): 333-349.

Kahneman, Daniel, J ack L. Knetsch and Richard H. Thaler. 1991. "Anomalies: The Endowment Effect, Loss Aversion, and Status Quo Bias." J ournal of Economic Perspectives 5 (1): 193-206.

Levy, Santiago. 2006. Progress against Poverty: Sustaining Mexico's ProgresaOportunidades Program. Washington, DC: Brookings Institution.

Marx, Karl. 1992 [1867]. Capital, volume 1. Harmondsworth, UK: Penguin.

McCloskey, Donald. 1993. "Some Consequences of a Conjective Economics." Chapter 4 in Marianne Ferber and J ulie Nelson, eds. Beyond Economic Man: Feminist Theory and Economics. Chicago: University of Chicago Press. 
Morduch, J onathan and Rachel Schneider. 2013. The USFD Methodology: The financial lives of low- and moderate-income Americans. US Financial Diaries Project, Issue Brief. October. http:// www.usfinancialdiaries.org/issue2-method917

Samphantharak, Krislert and Robert Townsend. 2009. Households as Corporate Firms: An Analysis of Household Finance Using Integrated Household Surveys and Corporate Financial Accounting. Econometric Society Monograph. Cambridge, UK: Cambridge University Press.

Simmel, Georg. 2011 [1900]. The Philosophy of Money. London: Routledge (Reprint).

Soman, Dilip and Amar Cheema. 2011. "Earmarking and Partitioning: Increasing Saving by Low-Income Households." J ournal of Marketing Research 48, November: S14-S22.

Stigler, George, and Gary Becker. 1977. “De Gustibus Non Est Disputandum.” The American Economic Review 67 (2) , March: 76-90.

Thaler, R. H. "Mental accounting matters." 1999. J ournal of Behavioral Decision Making, 12(3), 183-206.

Thaler, Richard. 2015. Misbehaving: The Making of Behavioral Economics. New York: W. W. Norton.

Thaler, Richard and Cass Sunstein. 2008. Nudge: Improving Decisions about Health, Wealth and Happiness. New Haven: Yale University Press.

Thomas, Duncan. 1990. “Intra-household Resource Allocation: An Inferential Approach.” J ournal of Human Resources 25(4): 635-664.

Tversky, Amos and Daniel Kahneman. 1974. "J udgment under Uncertainty: Heuristics and Biases." Science 184 (4157): 1124-1131.

Walras, Leon. 2010 [1874]. Elements of Pure Economics. London: Routledge.

Zelizer, Viviana. 1994. The Social Meaning of Money. New York: Basic Books.

Zelizer, Viviana. 2011. Economic Lives: How culture shapes the economy. Princeton, NJ : Princeton University Press.

Zelizer, Viviana. 2011. “The Gender of Money.” Wall Street J ournal Ideas Market Blog. January 27, 2011. Available at http:// blogs.wsj.com/ideasmarket/2011/01/27/ the-gender-of-money/ 